\title{
Professor Heinrich W. Herzog (1920-2014)
}

Born and raised in Zollikon, Heinrich Herzog graduated in medicine in Zürich and Geneva. He received postgraduate training in Chur, Davos and Basel as well as in Paris and Boston. He must have realized early on that wide-ranging national and international professional training is part of a solid foundation for his career.

In 1951 Heinrich Herzog began working in what was then known as the 'Bürgerspital' before being renamed the 'Kantonsspital Basel'. The University of Basel appointed him as an Associate Professor in 1959 before awarding him a full professorship in medicine in 1963. The hospital management had already entrusted the running of the Department of Respiratory Diseases to him in 1960. He led this department very successfully for 25 years before being given emeritus status in 1985 .

Thanks to his excellent didactic style, his innovative way of thinking and his sparkling optimism he succeeded in doing more than just imparting expertise to innumerable medical students and young doctors: he also managed to inspire the 'feu sacré' for medicine in them. Senior Consultants, Chief Physicians and University Professors were able to kick-start their career or get it on track thanks to the time they spent under his tutelage.

Several honors and distinctions were bestowed upon Heinrich Herzog (e.g. the Murray Kornfeld Memorial Founders Lecture of the American College of Chest Phy-
Heinrich W. Herzog

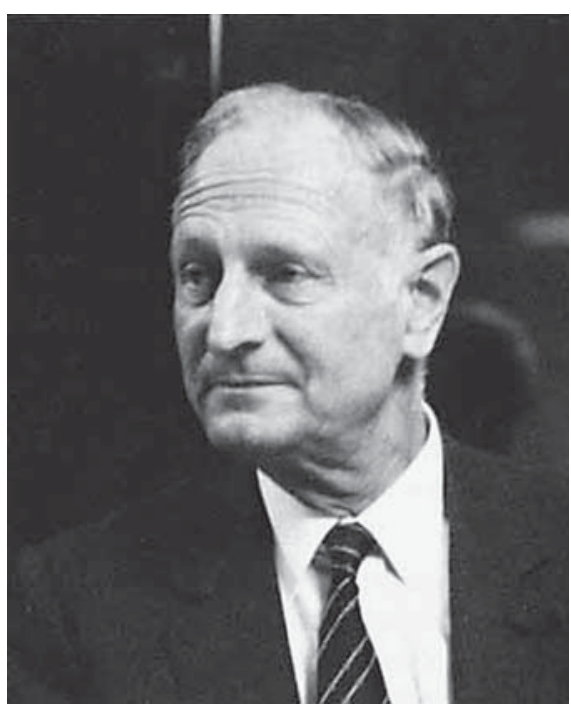

sicians). He was an honorary member of numerous specialist medical societies (in Germany, England and Switzerland as well as in other countries) and the author of more than 200 publications dealing with his area of expertise. He was also the chair of several international medical societies. In addition, from 1962 to 1997 he was Editor-in-Chief of the journal Medicina Thoracalis which is today published under the title Respiration. 
One of the greatest legacies Heinrich Herzog has left us is to have laid the foundations for the development of clinical pneumology. He managed to completely transform the then physiology - ensconced within the walls of sanatoriums - and established the modern discipline of pneumology in the university hospitals. He went on to blaze a trail for the introduction of modern technologies and in the process revolutionized the field of respiratory diseases: bronchoscopy still plays a crucial diagnostic and therapeutic role even today, as does modern pulmonary function diagnostics. Within this context, he can be viewed as a pioneer of something of quintessential importance today - translational research. The enormous scope of his clinical and scientific activities brought Heinrich Herzog great respect not only in Switzerland but also in the adjoining countries and in the United States.

Heinrich Herzog, however, never stopped being a doctor. He was very good at listening to his patients and tried to help them even when there were hurdles or when their condition presented a medical challenge. A patient visit- ing his consultation always had his undivided attention. Many of them benefitted, and amongst them was also Nelson Mandela. He was once a patient of the Basel-based doctor and scientist who had been summoned to his sickbed in South Africa. At the time Mandela was still in prison, and when Heinrich Herzog came home it was evident that this particular inmate had made a deep impression on him. While he had been happy to accept this international mission, he had not allowed his attention to be distracted from those issues which he as a doctor perceived to be truly important.

Indeed, it is against this background that we shall always remember Heinrich Herzog: he was an enthusiastic teacher and an innovative researcher, but above all else, he was a true physician whose dearest and most heartfelt wish was to minister to those with medical needs.

Prof. André P. Perruchoud, Former student of Heinrich Herzog

Dr. Martin Frey, President of the Schweizerische Gesellschaft für Pneumologie 